\title{
WOMEN STORIES OF THE VIOLENT CONFLICT IN POSO AND TRAUMA HEALING
}

\author{
Y. Tri Subagya \\ Sanata Dharma University, Indonesia \\ tsubagya@gmail.com \\ DOI: https://doi.org/10.24071/ijhs.2018.020111 \\ received 5 July 2018; revised 2 August 2018; accepted 30 August 2018
}

\begin{abstract}
This article intends to unfold women experiences in coping with trauma of the violent conflict and their efforts to release its burden. In the last decade, the victims of violence are referred to get a psycho-theuraphy of trauma due to their depression from the disaster. Development agencies often initiate the program of trauma healings for the victims with the posttraumatic stress disorder (PTSD) model, especially for women who were described as passive actors and became the most vulnerable victims in the violent conflict. The fact that women were involved in the conflict as active social actors was less accounted due to the healing mechanism. Their experiences, such as individual memories on vengeance and struggles for family survival tend to be inarticulated, except their attempts to forget traumatic burdens. This article defines the articulation of women stories as both a crucial factor in healing their past traumatic experiences which in turn the stories could be as an effective approach to pave a way for reconciliation. The contribution of narrative for releasing the burden of traumatic experiences from the past atrocities has been the subject of the recent discussion in the academic field.
\end{abstract}

Keywords: Poso, trauma healing, violent conflict, women stories

\section{Introduction}

The series of violent conflict become a part of historical narratives in Indonesia. Even, after the country independence from Dutch colonialism, violence continuously displayed particularly during the authoritarian New Order regime between 1965 and 1998 (Anderson, 2001 \& Schulte Nordholt, 2002, pp. 36-42). Indeed, the violence also happened during Soekarno regime, the predecessor of the New Order, but it was less massive and brutal. In this period, violence was instigated by the state mainly to overcome separatism and rebellion, such as the Darul Islam/ Tentara Islam Indonesia (DI/TII) rebellion of Kartosuwiryo in West Java and Kahar Muzakar in South Sulawesi, the communist party revolt in Madiun, 1948, the proclamation of Republik Maluku Selatan (Republic of South Moluccas, RMS) in 1950 and Pemerintah Revolusioner Republik Indonesia 
(Revolutionary Government of Indonesian Republic, PRRI) in Bukittinggi 19581962.

If military operations against anti-state insurgencies constituted the main efforts of Soekarno's government to reach unity in diversity, Soeharto's New Order deployed military operation to strengthen his power. Beginning with the extermination of hundred thousands of communist party sympathizers in 1965 after the military took over power from Soekarno, violence was used again and again by the New Order to silence people who criticized or subverted the regime (Hüsken and de Jonge, 2002, pp. 1-10). State violence was, for example, perpetrated in several regions, e.g. the military invasion of East Timor in 1975 (Simpson, 2005, pp. 285-291), the Petrus or 'mysterious killings' of criminals in the 1980s (van der Kroef, 1985, pp 745-759), the military attacks against an Islam radical group in Tanjung Priok in 1984 (Thufail, 2010, pp. 211-212), as well as against an Islamic radical group in Talangsari, Lampung in 1989 (Fadilasari, 2007), and the military operations in Aceh between 1970s and 1990s (Robinson, 1998, pp. 129-132). The collapse of the New Order did not result in the end violence in Indonesia. Due to the weakness of the state after Soeharto's downfall, violent conflict between ethno-religious groups erupted in several regions, such as between Dayak and Melayu against Madurese in the West Kalimantan and Central Kalimantan, as well as Christians against Muslims in Kupang, Ambon and the North Moluccas and Poso.

In Poso, the collective violence between Muslim and Christian groups was triggered by the fight between youth gangs whose members had the different religious identities in December 28, 1998. Since then, the tension between Moslem and Christian communities continuously heightened and sporadically broke out into violence in several villages. There was no exact number of casualties and victims, but the estimation was more than a thousand people dead, thousands more injured and more than 145,000 persons displaced. It was about a half of the district population seriously affected with the conflict which at the time amounted 231,893 (Badan Pusat Statistik Poso, 2001). Among the property damages, there were more than 12,000 houses and public buildings burned down. Livelihood and economic activities were paralyzed while people lost their material belongings and disintegrated from their familial ties as well as distrust to their neighborhood and communities.

As the escalation of the violent conflicts was up and down along the time, observers and mass media generally oversimplified the chronology of Poso conflicts into five phases. First phase was in 25-29 December 1998 when the fight of youth dragged the religious identity into the social unrest that was then controlled by state apparatus and religious leaders. The second phase occurred in 16-22 April 2000. Again, youth gangs fighting in the bus station provoked the different religious communities of Islam and Christian into an open battle. Houses, churches and schools in several villages in the district of Poso Kota were burnt down. In this phase, the battle was still isolated in the urban center of Poso. The third phase erupted on 24 May to 2 June 2000 in which it was speculated as the retaliation of Christian groups against the attack to their communities during the second phase. The nuance of religious violence was salience in this conflict because people were split into two different religious identities. In the name of solidarity, people from other regions began to arrive in Poso to support their 
groups in the battle field. The attack and raid on religious symbols reaches the climax in the fourth phase from July 2 to October 23, 2000. The conflicts were exacerbated with the arrival of jihad militia from Java and South Sulawesi in July 19, 2001. The battle between two communities continued with greater escalation and spread widely to rural villages. More houses, churches and mosques became the target of raid. People who fled from their home were divided in accordance with their religious alignment. After being interrupted for a week, the battle continued to break out in the outskirt of Poso, which was then called the fifth phase (November to December, 2001). This last phase happened prior to Malino peace accord intervened by the central government team from December 19-20, 2001 (Ecip, 2002; Damanik, 2003).

However, the violent conflict had not come to end with the peace accord although the mobilization of the groups in the open battle declined after the agreement. The attack then turned into underground and sporadic terror. The target was no longer religious groups, but persons in public areas. Since the agreement of Malino, there were still incidents of mysterious killings, random bomb explosions, and abductions. The police alleged that the perpetrators of the violence after peace agreement were groups connected with Asian terrorist network that backed them up with military training and automatic weaponry support (Tempo, 2 November 2003; ICG, 2006 \& 2007, McRae, 2016). The deescalation of violence took place gradually after peace accord and various efforts of grass root reconciliation, judicial prosecution and security measures to restore coexistence.

Like in the other areas of conflict in Indonesia, the violent conflict in Poso brought about bitterness and suffering to people who lost their families, and displaced from their home and neighborhood. More than that, it was also disrupted social solidarity, kinship relations or other social ties that it turned into prejudice distrust and hostility. The effect of violence led survivors to shoulder the traumatic burden that affected not only individual relationship, but also social cohesion of the community.

\section{Theory}

\section{The trauma project and survivors of mass violence}

One of the common popular programs during the conflict in Poso was trauma healing therapy. Humanitarian agencies, Non-Government Organizations (NGOs) or relief workers carried out the program to response stress and depression of the violent survivors. Their activities were often integrated with other services i.e. food distribution and shelter building in the refugee camp, micro finance, health service provision, water and sanitation, to dialog for reconciliation, etc. In the absence of government intervention, their activities were important due to the need of victims and survivors. Unfortunately, most of NGOs were dependent on the fund support of the donors. So, when the donors had leaved them, their activities did not last long. It could be reflected from the declining number of NGOs and grassroots activities after international agencies and donors moved out their humanitarian programs into natural disaster relief in other parts of Indonesia. Certainly, few local NGOs and social workers were still persistent and 
continuously facilitated peace buildings indiscriminative to people in their activities.

Regarding with the trauma healing activities, the relief agencies assumed that the program were urgent because people getting accustomed to frequent random acts of violence during the conflict. They became numb and insensitive due to the suffering from a constant threat of violence exposure. So, they had to be assisted to release their traumatic burdens such as witnessing widows who were lost children or husband in front of their eyes, finding children whose parents were killed on the street or watching their houses and properties were burnt down, etc. A psychiatric consultant in the trauma healing program said that she found many symptoms of posttraumatic stress disorder (PTSD) such as depression, flashbacks, insomnia, nightmares and even worse, the signs of being insane in the area. She convinced if the mental disturbance left untreated it could debilitate an individual permanently, and expressed itself in physical manifestations. The mental health problems could affect entire families, for instance, if a mother is too depressed to leave her home, her children must bear this burden alone. The impact of mental health could also be serious for the community as it could spin them into a spiral of violence in which out-group hostility and vengeance remain intact.

Dealing with the situation, such as trauma healing program was certainly needed as priority but the method and approaches to carry on the activities should be put into consideration. Healing or psychological recovery would make the life of the survivors getting better, reducing vengeance and help them becoming open to engage with process of reconciliation (Kriesberg, 1998; Staub, 2006). Nonetheless, the wrong mechanism of the healing program could lead to maltreatment or victimization of the survivors because the survivors of the violent conflict were different with the victim of criminal or domestic violence. The PTSD model that was often adapted as trauma healing model was certainly insufficient while the humanitarian agencies that supported the process might not realize its impacts (Pintar, 2000, pp. 59-60; Silove, et al., 2007).

Several warnings are alarmed by the scholars dealing with the trauma healing activities for the victims of collective violence in which the idea grounded from the PTSD. Silove and his colleague (2007) critically reminded that the concept of psychological trauma based on Western culturally bond theories on psychopathology rather than cross culturally applied to describe psychological problems. PTSD was created for historical and political reasons, particularly to legitimize the suffering of USA veterans from the Vietnam War. So, the underlying context of the use was specific that it could not be applied without understanding socio-cultural context of the violence. This point is true to my experiences since the victims and survivors of collective violence would rather keep their traumatic memories for themselves due to the fact that they remained living together in their neighborhood with the perpetrator. Moreover, if we asked them to identify their problems aftermath violence, they rarely mentioned having mental problems.

The symptoms as indicated by PTSD are also generic and normative like reactions of anxieties so that it should not been defined as illness or abnormality. Local concepts of stress or other forms of depression do not specify as symptoms of PTSD. They have their own constructs and attributions in relation to mental disorder. The traumatic memories could not be solved by personal therapy 
isolated from the socio- political and cultural context. The individual memories could be understood by linking the individual experiences with the collective history of the communities because the memories are meaningful to survivors in that serving to mourn losses, strive for justice, learn from the past and maintain a cultural legacy of a society's history. In this regard, the trauma healing should be put in socio-cultural context to support reconciliation by redeveloping trust and reweaving social fabrics torn by the conflict and atrocities.

The complexities of violent conflict made a difficult to define victims who needed help for healing traumatic burdens. One day someone become victim, on the other day they could become perpetrator, and vice versa. The common expression was that everyone felt as the victim who was the most suffering from the conflict. Some of my informants in Poso also told that they recognized a few of their neighbors either taking a part in destroying their houses or doing nothing when strange people attacked them during the conflict. Most of them also remembered that the targeted houses being burnt down seemed to be selected. The dominant Christian villages were attacked by those people who worn and yelled Muslim attributes. Oppositely, the dominant Moslem settlement was also ransacked by allegedly Christians dressing in black shirts with red bandana. They wondered how the harmonious life in their areas was torn by the conflict and the religious symbols could inflame them into a series of bloody violence. Indeed, people were also confused of what really happened in the area.

During the conflict, women and men have different experience and problems due to the different gender role and sexuality. In several cases, women were not harmed by people who attacked their villages because they were neither seen as the threatening enemy nor regarded as being responsible for causing the conflict. Some women said they were released without physical injuries when their villages were under the siege of the enemy. But, they had to flee due to the uncertain situation. While men were obliged to defend their villages or to seek the way out escaping from the violence, women took care of children and the elderly in looking for safe places. They did it simply because there was an absence of men along with them as well as for life. In refugee camp, women's struggle to make a living in any remunerative activities for the survival of their family when men lost their job or were absorbed in voluntary emergency programs such as the reconstruction of their destroyed villages and public facilities (Putranti \& Subagya, 2005).

Rarely and only exceptionally did women perpetrate in violence. A few of women indeed mentioned that they joined the groups as combatants during the conflicts, but their roles were just to give support to their men in the battle field, such as providing logistics for the group in defending their villages or praying for the awakening of their bravery. A woman who once joined the civilian paramilitary group told me that there were only seven women in her paramilitary group. Like her, the women became combatants because they were angry and wanted to take revenge for her parents' death. They joined simple military training for the battle, but they were never in the frontline because their task was to prepare logistics and to take care of injured combatants. Together with the other members of combatants, she eventually quitted from the group after realizing that the conflict would not be solved by vengeance. 
Women were marginal because of masculinity character of the conflict and the gender division of labor in the community. The marginal position of women had been taking place even before the violent conflict. The division of labor between men and women seemed complement one to another but the status and its relation was not equal. Compared to men, women were lack of accessibility and less involvement in any public sectors. During the conflict and its aftermath, women expanded roles in the public spheres for the family survival since men productive activities were reduced by the insecurity and distrust within the conflicting communities. The greater role of women also appeared in their involvement in the institutions and women's organizations in promoting reconciliation and peace building, but they were still excluded in the formal political discourse and less represented in the decision making even if the decision was addressed to tackle their problems. The government policies were even discriminative to women in a sense that any program beneficiaries in grassroots level only registered men as the household head. Furthermore, violence against women as the effects of the conflicts remained being neglected.

Due to complexities of the violent conflict, trauma healing activities should be integrated with the larger process of reconciliation. If the trauma healing model is only isolated to personal therapy like the PTSD, it is not sufficient (Mendeloff, 2009, pp. 613-614). In the collective violence such as in Poso, the survivors and the victims lived together with the unrepentant perpetrators in the same area. Moreover the stronger ethnic and religious identification and social and residential segregation as result of the conflict limited their social space of interaction. In this condition, trauma facilitator might also be hardly to work if the facilitator was demanded to stand up in "neutral" position among the groups while there would be enormous people who claimed as victims of the violence.

\section{Theory Application}

\section{Story telling as trauma healing and a pathway of reconciliation}

Telling story is the mechanism to release traumatic burdens of individual experience. Psychiatry makes it as the therapeutic method and considers it as the appropriate mechanism for people who were stress or suffered under the oppression. By telling their experience about the horrific events, they have undergone facilitates the recovery. If the story telling is intended by psychiatrist to cure the client and keep it confidential for clinical record, the social scientist and humanitarian agencies use the document of the story in the mass atrocity or collective violence as part of reconciliation process. The use of storytelling for both purposes has been recognized by the humanitarian agencies and human right activists, but in practice it is often carried out in the separated programs and unrelated one to another (Pintar, 2000; Chaitin, 2003; Zurburchen, 2005, Mendeloff, 2009).

The potential worth of storytelling to heal the traumatic past experience and reconciliation process relate with the human basic capability that is capacity to speak. It mediates the construction of individual identities and positions in relation with other people and communities (Senehi, 2000, pp. 103-104). Dealing with the past violence, storytelling leads the healing of the traumatic experiences through a process by which the feelings of shattered pieces of the self are reconnected. The process have to involve state representatives or truth commission and publicly 
acknowledged since the individual stories are part of larger narrative of their past violence and to know that one's suffering is not solely a personal experience. The state support of the truth telling would make the past events became the lesson and prevent the reoccurrence of the atrocities or violent conflict in the future.

Storytelling refers to speaking about one's life. It manifests a capability of what it means to be human. In relation with the notion of justice that is a fundamental part of reconciliation, the story telling becomes a vital process to attain it. There are six dimensions of the story telling in relation to justice. First, the story telling is an essential human activity in that people make their life meaningful. Second, the story telling constitutes to restore the victim's ability to speak or to tell story with their owned words that was taken away by the uncertainties and horrible condition during the violent conflict. It was particularly to the victims who were tortured as they were forced to follow the language of torturer who show of their superiority. Third, storytelling reveals truth, especially in the free atmosphere without constraints of talk such as in judicial process. Fourth, stories serve as translation, communication and recognition. In the conflict situation that are deeply divided communities culturally, economically, politically, the sharing of personal narratives could be the only means by which such diverse people can begin to understand each other. When stories translate events into a shared language, they arouse our emotions. It can express and transmit human emotions such as pain, loss, separation, desperation. Stories provide a common language by which the less powerful can communicate with the powerful. The public act of storytelling can lead to both self and mutual recognition. Fifth, the story telling is a kind of ritual that renewed the status of one who told their stories by acknowledgement of the audience. It reborn individuals in new social space where allows them to talk freely and to be liberated from the forms and fears that might restrain them. Sixth, the story telling make the invisible memory of the past could be remembered. It enables past oppression, pain, atrocity that was shattered putting back together. It gives them a meaning and learning materials to prevent the recurrence of atrocityy in the future (Phelps, 2006).

Taking into accounts the victim's experiences is substantially significant not only to understand the causes of the conflict, but also to look for the ways for social reconciliation. Within their experiences, there are collective memory, psychological burden of trauma and perhaps vengeance. By listening to their experiences, we can learn the other side of historical narratives as well as their aspirations for the conflict resolution. It is due to the fact that the experience of violent conflicts, as with social life, is not built upon a single discourse. It is constructed from a stock of available discourses that are shared with other individuals and social groups. Indeed, the concept of truth has no single meaning as it disentangles from the power relations. There is multiple meaning of truth in the discursive practices by which the meaning is contested and unstable. In this limitation, truth underlies ethical consideration of social justice at least for victim and survivor of violence.

From the victim perspective, the need to tell truth stories of the past violence and the demand for social justice is very fundamental. Priscilia Hayner (2002) shows a variety of benefits to enforce telling the truth for uncovering secret abuses and legacies of violence. Accordingly, Zurbuchen (2005, p. 11) pinpointed the advantage of the Truth Commission including clarification and 
acknowledgement of 'what happened', through lifting veils of denial and secrecy; responding to the needs and interest of victims, through enabling them to tell their stories and have their suffering recognized; contributing to justice and accountability through gathering information that may be used in formal legal proceedings; outlining institutional responsibility and recommending reforms; and promoting resolution of conflicts and reduction of tension. However, not all countries could accept the founding of truth commission due to the remaining strong position of the agents who supported the violence still dominant in negotiation for the state's rule and policies.

In Poso, several attempts to end the conflicts have been made since the outbreak of the violence but the efforts did not meet a sense of justice in the grass root. ${ }^{i}$ Meanwhile, the legal process got stuck since each community intimidated the juries, prosecutors and witnesses or even provoked mass violence whenever people that belonged to their group was prosecuted on trial. ${ }^{\text {ii }}$ Despite the stagnancy of judicial system, the peace agreement that had been made was not really implied on true reconciliation because the agreement were focused on the consensus to end up group mobilization, and to build peace as well as to reconstruct the public facilities, but absence for revealing truth and public acknowledgement of the conflict. There was no recommendation in the peace agreement to seek the truth for the grassroots that wanted to know what had been really happening in their area. However, the conflict gradually declined along the time in the area, but leaving the population traumatic burdens of the past as appeared in the sharply social and residential segregation based on ethno-religious identities.

\section{The domains of woman stories and their agencies for reconciliation}

The experiences of women in Poso were more or less similar with stories of women in the other conflict areas in terms of gender based violence, discrimination and injustice. But, it was specific in relation to the local context of the conflicts, in which ethnic and religious nuances became salient identification. There were several topics of traumatic events which people told me during my fieldwork in the area. These include depression for the death of their spouse, family members or relatives; suffering for family survival, material lost and the damage of their properties; flee looking for safe place in that they had to move or to hide several times; protecting children or family members due to the absence of their spouse; flexibility make interaction crossing ethnic and religious boundaries that was sharply divided during the conflict; participation of violence supporters from other regions who exacerbated situation; the late intervention of state and security apparatus to assist them in their danger or midst of difficulties; forgiving people who had made them sufferings, but not forgetting their wrong doing in the past. Several women also suffered from sexual violence such as sexual harassment, forced abortion, rape and battering. Certainly, there were much more various topics spoken depending on situation and persons who we encountered, but the domain of stories above were repetitively articulated either by the same informants or other persons in the different times whenever I talked with them. ${ }^{\text {ii }}$

In the absence of government to set up truth commission, the reconciliation process in the grass root was initiated by NGOs and civil society elements. The organizations worked in a wide range of activities such as trauma healing and 
provided assistance for the socio-economic rehabilitation in the post conflict as well as redeveloping trust in the community. They also involved women as the main actor of reconciliation at the grass root. It was assumed that women had no interest with the conflict root. So, women were relatively less prejudice and inclusive in social interactions. The socio-economic intervention would empower their position, and by extension their household resilience. Thus, together with women's engagement in the socio-economic activities, the social reconciliation could be enhanced in the community.

Besides non-government organization's support through their programs, women had been playing a prominent role to reweave social fabric in the grass root that was torn along with the conflict. While men kept up their past memories of the other groups as threatening enemies, women interacted and developed the mutual understanding among them to end the conflict. Women had less burden of fear to interact with others. When the tension of the communal conflict was still high, they could still safely cross over ethnic and religious boundaries. Some of them could made cooperation in small business activities as well as encouraged the recovery either in the refugee camp or in the villages. Some others who were engaged in the public domains such as civil servants, traders or peasants also smartly rebuild social relationship not only among their colleagues and clients, but also among wider societies.

The reconciliation in that women played as key actors went on in two different levels. At the household level women responsibility to educate children enabled healing traumatic experience of their children from the bitterness of conflict. At the community level, those who became traders, teachers or religious leaders, etc enable to cross borders of ethno-religious segregation and build trust among the conflicting groups through their activities. Women initiated and participated in any public gatherings for reconciliation in many villages. Their greater involvement in public spheres contributed to the development of peace. Through their engagement in public arenas, they could tell to different community members about the recovery situation of everyday life in their areas. To the extent of social reintegration, such activities pave a way for reconciliation in regard to the decline of social trust and a sense of insecurity.

Even though women play important role in promoting reconciliation and peace, many obstacles hindered them to fully participate in the peace building process and activities. This limitation stemmed from cultural constraints in that the ideal type of woman was those who were obliged to take care of household chores and to look after their children. Doing activities outside their house was considered an extension of their responsibilities to keep up their household welfare. Women's involvement in public space was mainly intended as a protection for their families and communities rather than with a conscious attempt to the development of peace. Aside from that, their contribution in the reconciliation process was neglected by the government. Only a few women were in fact involved in the decision making for peace building, and they were not assigned for rethinking about appropriate public policies sensitive to women's problems. Most of the reconstruction programs after the conflict were gender bias in a sense that the programs were undifferentiated in their implementation, specifically to women's problems such as reproductive health, vulnerability to 
sexual violence, and women's accessibility to public services. It was an irony that the potential role of women as the important agent for reconciliation process was less supported by the state and formal institutions.

To overcome the conflict needs an integrated approach. To end violence, the agreement of leaders of the conflicting groups to ceasefire was not enough. It was neither adequate solution if the government only deployed more security troops and rebuild the destroyed public infrastructure, but they did not pay attention to the victims and vulnerable groups. The reconciliation was also not enough with asking forgiveness without addressing social justice. In this way, the collective memory of the bitterness from the violent conflict should be properly reconstructed by seeking truth, and their past psychological wounds should be healed by public recognition and rehabilitation. The meaningful reconciliation could not be achieved without justice in that it based on the fundamental human rights including women who experience the conflict differently and have different access to resources.

\section{Conclusion}

The violent conflict has multi-dimension effects on the victims. It was not just a matter of losing or damaging their properties, but also leaving traumatic burdens to people whose family member died, and displaced from their homes. The violent conflict had also disrupted social solidarity, kinship relations or other social ties that it led to rising up social prejudice, distrust and segregation on the basis of religious and ethnic identities. Regarding with this complexities, the trauma healing program that is commonly proposed to heal the violent victims may inadequate if it is only reduced into individual therapy. It should be integrated and complement with other reconciliation activities to meet the needs of victims and to fulfil justice.

Storytelling which is used in the psychological therapy and also used as the media of telling truth in truth commission of several countries might be an appropriate mechanism to release the traumatic burden of the past violence. However, this mechanism needs sensitivity to local cultural context by which the stigmatization to the victims should be avoided and the re-victimization could be prevented. Women stories from the violent conflict in Poso gave a lesson how they could be key actors in the grass-root reconciliation while healing the wounded past through their interaction across the borderline of ethno-religious identities. However, their stories were less recognized in the formal peace process. None of their activities were accounted for the rehabilitation in the post conflict agenda. Women's stories in peace makings submerged in the dominant discourse on a conflict and its resolution that it highlighted only the grand narratives on formal peace accord, government rehabilitation programs and reconstruction activities.

\section{References}

(2007). Jihadism in Indonesia: Poso on the edge. Asia Report, 127(24), January 2007.

(2002). Perempuan di wilayah konflik. Jurnal Perempuan, 24. 
(2004). Perempuan \& pemulihan konflik. Jurnal Perempuan, 33.

(2001). Communal violence in Poso, Central Sulawesi: Where people eat fish, fish eat people, Indonesia No. 72, Oktober.

(2001). Changing forms of coexistence, in Reconciliation, Justice and Coexistence: Theory \& Practice. Abu Nimer, Mohammed (ed.) Lanham, Maryland: Lexington Books.

(2004). Operasi kelar "koramil" muncul. Media Sangkompo. 4, Juni-Juli. (2007). Perdagangan senjata di Poso, Edisi 5-11 February, pp 26-34.

Al-Anshari, F. \& Ahmad S. (2006). Tragedi Poso, Jakarta: MMI and FS-PUI.

Anderson, B. R. O'G. (ed.) (2001) Violence and the State in Suharto's Indonesia. New York: Cornell Southeast Asia Program.

Aragon, L. V. (2000). Fields of the Lord. Animism, Christian Minorities and State Development in Indonesia. Honolulu: University of Hawai Press.

Arifah R. et.al (eds). (2006). Perlawanan tanpa kekerasan. cerita-cerita dari daerah konflik di Indonesia. Yogyakarta: CSPS.

Badan Pusat Statistik Kabupaten Poso, (2000). Kabupaten Poso dalam Angka Poso: BPS.

Basri, M. (2007). “Kami Ini Hanya Kerbau”, Edisi 12-18 Februari.. pp30-32

Butalia, U. (2000). The Other Side of Silence: Voices from the Partition of India. Durham: Duke University Press.

Chaitin, J. (n.d.) Narratives and Story -Telling. http://www.beyondintractability.org/bi-essay/narratives

Columbijn, F \&Lindblad, J.T. (Eds.). (2002). Roots of violence in Indonesia. Leiden: KITLV Press,.

Coppel, C. A. (ed.) (2006). Violent Conflicts in Indonesia. Oxon: Routledge.

Damanik, R, (2003). Tragedi Kemanusiaan Poso.Menggapai Surya Pagi melalui Kegelapan Malam. Jakarta: PBHI, Yakoma PGI and CD Bethesda..

Darwis W. (2001). Kerusuhan Poso yang Sebenarnya. Jakarta: Global Mahardika Netama..

Ecip, S. S. et.al. (2002). Rusuh Poso, Rujuk Malino. Makasar: Cahaya Timur,.

Fadilasari T., (2007). 1989: Kesaksian Pelanggaran HAM Peristiwa Lampung. Jakarta: Lembaga Studi Pers \& Pembangunan \& SijaDo,.

Gogali, L. (2008). Suara Perempuan dan Anak menuju Rekonsiliasi Ingatan. Yogyakarta: Galang Press.

Hayner, P B. (2002). Unspeakable truths: Facing the challenge of truth commission. New York: Routledge.

Husken, F \& Huub J (Eds.). (2002). Violence and vengenc, discontent and conflict im New Order Indonesia. Saarbrucken: Verlag fur Eutwicklungspolitiek Saarbrucken GmbH \& Nijmeegs Instituut voor Comparatieve Cultuur - en Ontwikkelingsstudies,.

ICG. (2005). Weakening Indonesia's Mujahidin networks: Lesson from Maluku and Poso. Asia Report No. 103, 13 October 2005.

Klinken, V. G. (2007). Communal violence and democratization in Indonesia. small town wars. London and New York: Routledge..

Koaliasi Perjuangan Kesetaraan Perempuan Sulawesi Tengah (KPKP-ST). (2004). Siaran Pers Aksi Bersama Menolak!. Palu, 16 Juni. 
Kriesberg, L (1998) Constructive Conflicts: From Escalation to Resolution, Maryland: Rowman \& Littlefield.

Kroef V. \& Justus M. (1985). "Petrus": Patterns of prophylactic murder in Indonesia. Asian Survey 25 (7).

Mangun, N. H. (2002)."Perempuan Tulang punggung ekonomi keluarga pasca konflik (kerusuhan) Poso", Jurnal Perempuan, Vol 24.

Mappangara, S (ed). (2001). Respon militer terhadap konflik sosial di Poso. Palu: Yayasan Bina Warga Sulawesi Tengah.

McKay, S (2000). Gender justice and reconciliation. In Women's Studies Forum, 23(5), pp. 561-570.

Mcrae, D. (n.d.) Poso. Sejarah Komprehensif Kekerasan antar Agama Terpanjang di Indonesia Pasca Reformasi. Tangerang Selatan: Marjin Kiri.

Mendeloff, D. (2009). Trauma and Vengeance: Assesing the Psychological and Communal Effects of Post Conflit Justice. Human Rights Quarterly. Vol. 31, No. 3, pp. 592-623.

Moser, C. \& Fiona C. (2001). Victims, Perpetrators or Actors? Gender, Armed Conflict and Political Violence. New Delhi: Kali for Women,.

Nordholt, H. S. (2002). A genealogy of violence, in F. Colombijn and Th. Lindblad (ed), Roots of violence in Indonesia, Leiden: KITLV Press

Phelps, T. G. (2006). Narrative capability. In S. Deneulin et al. (ed.), Transforming Unjust Structures: The Capability Approach. Netherlands: Springer,

Pintar, J. (2000). Anticipating Consequences: What Bosnia Taught Us about Healing the Wounds of War. Human Rights Review. January-March,.

Putranti, B D \& Subagya, Y. (2005). Jerat Bantuan, Jerit Pengungsi: Penanganan Kesehatan Reproduksi di Poso Pasca Konflik. Yogyakarta: Pusat Studi Kependudukan- UGM \& Ford Foundation.

Robinson, G. (1998). Rawan is as Rawan does: The origins of disorder in the New Order Aceh. Indonesia. 66, pp. 127-157.

Ruagadi, A. E. S. et.al (2007). "Bersatu Kita Teguh di Tana Poso" in Alpha Amirrachman (eds), Revitalisasi kearifan lokal. studi resolusi konflik di Kalimantan Barat, Maluku \& Poso, Jakarta: ICIP and European Commission., pp. 202-270.

Sangaji, A. (2007). The security forces and communal violence in Poso. in Renegotiating Boundaries. Local Politics in Post-Suharto Indonesia. Henk Schulte Nordholt and Gerry van Klinken (ed.) Leiden: KITLV Press., Pp. 255-280.

Silove, D, Zachary, S \& Adrian, B. (2007). Mass psychological trauma and PTSD: Epidemic or cultural illusion? In John P. Wilson et. Al. (ed.). Crosscultural Assesmnet of Trauma and PTSD. International Psychology Series. pp. 319-336.

Simpson, B. (2005). “'Illegally and beautifully': The United State, Indonesian invasion of east Timor and the international community, 1974-76". Cold war History, 5(3), pp.281-315. 
IJHS, e-ISSN 2597-4718, p-ISSN 2597-470X, Vol. 2, No. 1, September 2018, pp. 101-113

Staub, E. (2006). Reconciliation after genocide: Mass killing or intractable conflict: Understanding the roots of violence, psychological recovery and a general theory. Political Psychology, 27(6), pp. 867-894.

Tempo. Penyergapan di Tanah Runtuh, Edisi 29 Januari-4 Februari. (2007, pp 2431.

Thufail, F. I. (2010). The social life of reconciliation: Religion and the struggle of social justice in post new order Indonesia. Journal of Social Science and Humanities. 3, pp. 205-214.

Varshney, A. (2010). Collective violence in Indonesia. Boulder, Co: Lynne Rienner Publishers.

Wijaksana, M. B. (2002). Reruntuhan jiwa: Trauma perempuan Poso. Jurnal Perempuan, 24.

Zurbuchen, M. S. (Ed.). (2005). Beginning to remember: The Past in the Indonesian present. Singapore: Singapore University Press \& University of Washington Press. 